IP Periodica Polytechnica Civil Engineering

\author{
59(1), pp. 45, 58, 2015 \\ DOI: $10.3311 /$ PPci.7050 \\ Creative Commons Attribution (1) \\ RESEARCH ARTICLE
}

\section{The Evaluation of Building Materials in Terms of Energy Efficiency}

\author{
Ízzet Yüksek
}

Received 24-09-2013, revised 26-06-2014, accepted 26-11-2014

\begin{abstract}
Buildings consume energy at different levels in every stage of the life-cycle. Building materials occupy a great share of this consumption. Therefore, the amount of energy consumed by materials used in building during their life cycle is an important parameter in determining the energy efficiency of the building. In this study, the importance of energy-efficient material selection in designing "Energy-Efficient Building" is considered and discussed. It is possible to evaluate some building materials in Turkey in the framework of energy efficient building material criteria. This information is considered as a guide for users and employees of the building sector. As a result of the study, the selection of building material and energy efficient features of building materials are important parameters for the provision of energy efficiency.
\end{abstract}

\section{Keywords}

Building-Energy Relations · Building Materials · Energy Efficiency $\cdot$ Energy Efficient Building $\cdot$ Environmental Effects

\section{Ízzet Yüksek}

Department of Architecture, Faculty of Fine Arts, Design and Architecture, Celal Bayar University, Şehzadeler, Manisa, 45100, Turkey

e-mail: izzetyuksek@gmail.com

\section{Introduction}

Energy is one of the most important factors in economic growth and social development in all countries [1]. For this reason, as in the world, it is observed that the $\mathrm{CO}_{2}$ emissions concerning energy have increased in the last 20 years [2]. According to the data of "World Energy Report" which is annually published by British Petroleum and used as a reference in global energy sector, $1 \%$ of the total energy generated in the world was consumed by Turkey. According to the report, energy consumption in 2012, increased at the rate of $1.8 \%$ in the world comparing to the previous year, however, in Turkey, it increased at the rate of $0.6 \%$ [3]. Only $27 \%$ of the energy demanded by Turkey is met by domestic resources [4]. According to the data of 2012, the energy import bill of Turkey increased at 60 billion dollars [5]. In summary, Turkey is an energy importer and currently cannot utilize its domestic energy resources adequately.

The construction activities occupy $38 \%$ of total energy consumption of the world [6]. According to the data of 2008, in Turkey, the share of building/service sector in total energy consumption reached 36\% [7]. Construction sector must take more responsibilities to the environmental problems. In every phase of construction life-cycle, energy is consumed at different levels. In this consumption, construction material has an important share. For this reason, the energy consumed by the building materials during their life cycle becomes a significant parameter in the determination of energy efficiency of the construction.

Energy efficient materials can support the constructions both ecologically and economically because of their environmental positive features. Moreover, materials consuming less energy at the same time causes less harmful emissions and decrease the environmental pollutions resulted from the construction materials. Furthermore, with their various thermal properties (like heat storage, heat retention) they make contribution to the creation of comfort in indoor environment [8]. Finally, because of these reasons, taking energy efficient properties into account together with many criteria is necessary for environmental aspect during the selection of the proper material at the beginning of the design process. In this study, the parameters providing energy efficiency to the construction materials are discussed and var- 
ious construction materials are considered in accordance with these parameters. This information will be a guide in the selection of the proper material that raises the energy efficiency of the construction.

\subsection{Energy consumption in the building}

Energy consumption is rapidly increasing due to the increase in population and urbanization. Residential energy requirements vary from region to region, depending on climate, dwelling type and level of development [9]. The construction activities consume $38 \%$ of the globally used energy every year [6]. There is a growing concern about energy consumption in buildings and its possible adverse impacts on the environment. These are issues that the building professions in the whole world have to address [10].

In Turkey, regarding energy efficiency, in the process of EU (European Union) membership, in 2007, "Energy Efficiency Law" was accepted [11]. In this context, "The Regulation of Energy Performance in the Buildings" which was enacted in 2010, aimed to increase the energy performance in the buildings [12]. In accordance with this regulation, primarily, it is targeted to make the newly constructed buildings which have "Energy Identity Certificate". Besides, there is a standard which includes heat isolation rules for the constructions. TS 825 standard which was firstly prepared in February 1970 with the name of "The Rules of Protection Against Heat Effects in Constructions" and published, was renewed at different times and it was enacted with its latest form on 22 May 2008 [13]. Except from the present law and regulations, concerning energy problem, in 2004, Turkey was a party to United Nations Framework Convention on Climate Change (UNFCCC) which is directed to restrict the greenhouse gas emissions. According to these regulations, energy must be saved and effectively used in construction sector as in other sectors including transportation, service, etc.

Buildings consume energy at different phases and for different purposes;

- In the manufacturing phase of construction, energy is consumed for having raw material of construction and manufacturing materials its transportation and building of the construction,

- In the phase of using, energy is consumed for providing proper inner air quality in accordance with indoor visual, thermal, acoustic comfort conditions, and for maintenance, restoration, and renewal of the construction,

- In the phase of destruction of the construction, energy is consumed for destroying building and debris removal, obliteration of the construction waste, recovery of some construction materials/components in the recycling process.

"Energy Efficient Design Approaches" have been developed to decrease the energy consumption of the constructions during life-cycle. The feature that distinguishes energy efficient design from other design approaches is that it aims to minimize the amount and cost of energy considering individual and social benefits in accordance with all the construction standards in a broad area; from the production of all materials and components that constitute the construction, the use of construction as well as its design and, its maintenance, operation to the selection and management of climatic systems [14].

With the application of some energy efficient methods, in the developed countries such as Netherland, Germany, Canada, Australia and Singapore, 30-90\% saving in energy consumption has been made in the constructions in the last decade. From the experiences in the USA, a well-designed building that has the same area and is using solar energy, comparing to conventional buildings, with 5 - 10\% first additional investment, makes about $50 \%$ energy saving [15].

In the energy efficient building design, the use of energy efficient building materials is very important since the construction materials can positively support the constructions in which they are used by reflecting their environmental features with their all other features into the construction. For this reason, for energy saving, it is important to select energy efficient building material in the beginning of design.

\subsection{Previous studies}

Several recent studies have attempted to designate energy efficiency, environmental effects in buildings and building materials.

Kumar et. al. have discussed the use of embodied energy and total energy for a given sample room. The paper focuses upon comparison of two types of structures using fire clay bricks and ash blocks structure. Though ash blocks are 3 times costlier than fire clay bricks, the use of ash blocks has considerably reduced the size of air conditioning system, total usage of energy and finally the total cost of building due to its light weight and insulating feature [16].

Jayasinghe has investigated and developed the embodied energy of different building materials (conventional building materials and alternative building materials). This study has also included the performance of different materials on operational energy. It is shown that the alternative building materials (cement stabilized soil blocks and stabilized rammed earth for walls, micro-concrete roofing tiles for roof and pre-cast reinforced concrete slab systems for floor) and systems may have either reduced or similar impact on life cycle cost, compared to the conventional building materials. According to the result of this paper, the embodied energy of alternative systems is either lower than or comparable with most of other conventional systems [17].

Bribian et. al. present the results of a Life Cycle Assessment study comparing the most commonly used building materials (Steel, aluminum, copper, PVC and glass) with some eco-materials (Brick and tiles, insulation materials, cement and concrete, wood products) using primary energy demand, global warming potential and water demand impact categories. The 
aim of the study is to deepen the knowledge of energy and environmental specifications of building materials, analyzing their possibilities for improvement and providing guidelines for the selection of materials in the eco-design of new buildings and rehabilitation of existing buildings [18].

Lee et al. explore the impact of different building materials (concrete vs steel) on the embodied energy of the building structure, and compare them with the Green Building Rating score attained under the material category for the same structure. As a result of the study, the embodied energy of the whole concrete structure is more significant than that of the steel or the hybrid structure. Besides this, the impact of building materials not only is limited to the embodied energy and the demolition energy but also to the operational energy of the building [19].

Reddy's paper focuses on certain issues pertaining to energy, carbon emissions and sustainability of building construction with particular reference to the Indian construction industry. Some examples of alternative low-energy materials (Blended cements, stabilized mud blocks, compacted fly ash blocks, rammed earth walls, composite masonry jack-arch roof system) were discussed and the embodied energy analysis of a building using such materials was compared with that of a conventional building (Load-bearing brickwork, reinforced concrete solid slab floor and roof, concrete tile flooring). The analysis shows that embodied energy of buildings using the lowenergy materials and techniques results in 50\% savings in total embodied energy. There is a large potential and scope for utilizing the industrial and mine solid wastes for the manufacture of building materials for promoting sustainable construction practices [20].

Huberman and Pearlmutter have compared a reinforced concrete skeleton building which was used different infilling masonry block types with other types. The objective of this study is to identify building materials which may optimize a building's energy requirements over its entire life cycle, by analyzing both embodied and operational energy consumption in a climatically responsive building in the Negev desert region of southern Israel - comparing its actual material composition (standard hollow concrete block and autoclaved aerated concrete block) with a number of possible alternatives (stabilized soil blocks and flyash blocks). It has been found that the embodied energy of the building accounts for some $60 \%$ of the overall life-cycle energy consumption, which could be reduced significantly by using "alternative" wall infilling materials. The use of the "alternative" building materials can reduce the initial production energy required for a reinforced concrete building by $30-40 \%$, or the equivalent of 25-30 years of operational energy. The energy saved cumulatively over a 50 - year life cycle by this material substitution is on the order of $15-20 \%$ [21].

Reddy and Jagadish have analyzed various building materials in terms of energy efficiency. The some following conclusions emerge. Soil-cement block is the most energy efficient among the alternative materials (Concrete blocks, steam cured blocks and burnt clay brick). Lime Puzzolana mortars have the lowest energy content when compared with other mortars like cement mortar, cement-puzzolana mortar, etc. The use of energy efficient alternative building technologies can result in considerable reduction in the embodied energy of the buildings. The load bearing soil-cement block masonry and stabilized mud blocks filler slab have resulted in $62 \%$ reduction in embodied energy when compared to reinforced concrete framed structure building and $45 \%$ reduction when compared with burnt clay brick masonry and reinforced concrete solid slab building [22].

In the studies achieved, the newly developed building materials and construction practices which have emerged as an alternative have consumed less energy primarily in the use phase in of the construction lifecycle comparing with conventional building materials and practices, and it has been observed that they have less environmental effect.

\section{The Criteria of Energy Efficient Building Materials}

For the building materials' energy-efficiency it is required to use energy less and effectively in every stage during the life cycle. Particularly, the proportion of the energy that is consumed for the production and transportation of the building materials and elements in the total energy consumption of the construction process is great. Therefore, the preference of building materials, in all the stages, from obtaining their raw material from nature to their manufacture, transportation, usage and demolition stages, provides the constructions with energy efficiency [8].

The choice of a given building material can have multiple effects on a building's energy consumption over the different phases of its life cycle, and as suggested previously, these effects can be contradictory-since properties such as high insulation value may yield relative savings in operational energy together with higher embodied-energy costs. The balance of these factors is especially significant since a building's external structure and envelope (roof, floor, walls and windows) tend to account for the greatest portion of its embodied energy [23].

The proportion of the energy, which is consumed for the manufacture of construction materials, to the total energy consumption during its life-cycle is considered to be approximately 50 years and it changes between $6 \%$ and $20 \%$ depending on the construction methods, climate and similar conditions [24]. The criteria that determine the energy efficiency of construction materials can be classified into two categories namely, directly effective criteria and indirectly effective criteria;

\subsection{The directly effective criteria}

The criteria that determine the energy amount consumed by the materials used in construction during their life cycle are directly effective in determining the energy efficiency of construction materials. The energy consumption of the building materials during their life cycle is realized in two different ways;

- The energy consumed at the beginning of the building material's life cycle. 
- The energy consumed during the usage process of life cycle of the building material.

The energy consumed at the beginning of the building material's life cycle expresses the energy consumed for having and processing the raw material of construction, material transportation of the raw material to worksite and in its practice. However, the energy consumed in the usage process of construction material's life cycle includes the energy consumed for some operations such as maintenance, restoration, renewal and changing [25]. The factors affecting the energy consumption of building materials during their life cycle are;

Local Material: In the total energy consumption of constructions, amount of energy spent for transportation of the construction materials to construction sites is considerable and also affects constructions' energy efficiency and economical cost. For this reason, if the construction materials are local material, and are manufactured in nearby places to the construction site as much as possible, energy consumption in transportation will decrease and that saving in transportation will give the construction an important ecological quality [8].

Recycled Resources: A large amount of energy is used in manufacturing many building materials. In the manufacture of building material, using recycled sources instead of the sources which are not newly processed material provides a considerable preservation of raw material and also a considerable amount of energy saving. Recycling building materials are essential to reduce the embodied energy in the building; for instance, the use of recycled metal makes considerable energy savings between the rates of $40 \%$ and $90 \%$ comparing the material produced from natural resources [24].

Natural materials are quickly obtained from renewable resources: Generally, the energy content of natural materials is lower than that of artificial materials since these materials are manufactured with less energy and labor cost. Such kinds of materials which are easy to be locally provided are generally among the renewable resources. Such vegetal materials used in constructions for instance, wood, bamboo, reed, straw, rye stalk, sunflower stalk, mushroom are the natural materials which are quickly gained from renewable sources.

Materials manufactured through low density industrial processes: The intensity of energy consumption in the first of these phases - for the production of buildings and their components - has increased dramatically with industrialization. In contrast to traditional building practices based on locally available raw materials and human energy, modern methods have allowed vast quantities of fuel energy to be harnessed in the manufacture of standardized, quality-controlled building products. The high temperature processes that are used to produce steel, aluminum, cement, glass and expanded foam insulation are prime examples [21].

Non-existence of heavy procedures in the manufacturing process will cause less energy consumption, which provides energy efficiency to materials. Using the developed technologies in industrial processes like heat recovery method reduces energy consumption. For instance, in cement manufacturing technology, using the shaft furnaces instead of the conventional rotary furnaces makes energy saving between $10 \%$ and $40 \%$. Similarly, the use of arc furnace instead of rotary furnace in steel industry makes about 50\% energy saving [24].

Labor intensive materials: Using highly qualified man power in manufacturing materials will reduce the processes based upon industry, and accordingly decrease the energy consumption.

Materials manufactured by using renewable energy resources: Especially renewable energy resources (solar energy, wind energy, etc.) instead of fossil fuels should be preferred as a primary energy supplier in the manufacturing process. For example, the adobe brick is dried using solar energy after it is molded.

Materials consuming less energy during the worksite process: The management of worksite, the need for electricity energy and machines in operation, heating and lightening affect the energy consumption of the worksite. As a result of the increase in mechanization in worksites, the electricity consumption has increased considerably as well [24].

Use of Durable Building Materials: Use of durable materials in the buildings makes them more resistant and long-lasting against various factors. This delays or eliminates the need of renewing material or maintenance due to impairment and ageing. In this way, it is saved from the energy spent for the material to be used in maintenance or renewing.

\subsection{The indirectly effective criteria}

The energy efficiency of a building material is measured not only by its energy consumption during its life cycle, but also by the effect of the construction process where it is used on the consumed energy at the stage of operation.

In the construction with building material, high thermal performance of the building material indirectly effects energy efficiency. In the stage of living in these constructions, energy is required to supply the comfort conditions for human health and high labor performance. This stage is the longest stage in the life-cycles of the constructions. Therefore, the needed energy increases, and this affects energy efficiency adversely. With the choice of building materials whose thermal insulation capacity is high, the energy amount that the construction consumes in its usage stage will be decreased.

\section{The Evaluation of Building Materials in Terms of En- ergy Efficiency}

It is not so easy to qualify building materials ecologically since they may have both positive environmental qualities and also negative ones. But, they should have environmental qualities as much possible. However, the indispensable property of a material is to be energy efficient since, as mentioned before, 
such energy efficient materials play an important role in building the construction where it is used. In this chapter, regarding the criteria explained in the former chapter, an assessment has been made in terms of the energy efficiency values of some frequently used building materials. Besides, a more detailed assessment can be made by increasing the number of sample materials in other studies.

Wood: Wood is a natural, renewable, long-lasting, process able and visual material. Furthermore, it is renewable and recyclable, when it completes its life time; it has the quality of self-destruction in the ecological cycle. The tree which is the source of wood stores carbon in the growth process, and does not consume energy in the process of gaining raw material as it is a natural source (Fig. 11.

The balance in equivalent carbon dioxide emissions is almost neutral, due to the low level of industrial processing and would be negative (net absorption of emissions) if product is recycled or reused instead of incinerated at the end of its life. We must consider that every $\mathrm{m}^{3}$ of laminated wood (not incinerated at the end of its useful life) absorbs $582 \mathrm{~kg}$ of $\mathrm{CO}_{2}$, while reinforced concrete emits $458 \mathrm{~kg} \mathrm{CO} / \mathrm{m}^{3}$ and steel $12.087 \mathrm{~kg} \mathrm{CO}_{2} / \mathrm{m}^{3}$ [18].

Energy is consumed at a low level only if is processed and dried. For example, in the production of solid wood parquet, simple wood processing machines that work only with electricity are used. The shaped parquets are dried in the furnaces that use the wood shavings while processing parquets (Fig. 1).

In a study carried out in New Zealand, the energy content of the wood has been found as $2.8 \mathrm{MJ} / \mathrm{kg}$ and $1179 \mathrm{MJ} / \mathrm{m}^{3}[26]$. Studies of various countries have shown that buildings with wooden structures require less energy and emit less $\mathrm{CO}_{2}$ during their life cycle than buildings with other types of structures [27-29]. Furthermore, according to TS 825, the heat conductivity of the wood is between $0.13-0.20 \mathrm{~W} / \mathrm{mK}$ [13].

It is highlighted from these values that both energy consumption content and heat conductivity of the wood is low. For this reason, they display energy efficient features both in the stages of usage and production.

Gypsums mud-brick: Adobe which is conventional building material has such negative properties as having low compressive strength and low moisture resistance. In order to overcome them, adobe with gypsum is produced adding cement, lime, gypsum and other additives into soil. Many studies have been conducted in different countries about stabilization of adobe with different materials [30-34]. In the studies carried out by Ruhi Kafesçioğlu, in Turkey, the negative properties of adobe have been reduced with gypsum. This adobe type whose qualities have been enhanced by $10-20 \%$ rate of gypsum added into the soil is called Alker (Fig. 2). In the manufacture of this material and - in its transportation to construction site, the energy consumption is almost - zero. The heat conductivity value and density value of Alker are $0,40 \mathrm{w} / \mathrm{mK}$ and $1550 \mathrm{~kg} / \mathrm{m}^{3}$, respectively. With these properties, energy efficiency is provided in the construction by preventing heat loss and storing heat [35].

The features that provide energy efficiency to the adobe with gypsum can be classified as following;

- With its high heat conductivity coefficient and thermal mass quality, by reducing the energy amount needed to supply the proper comfort conditions within the construction, it saves energy in heating/cooling of the construction, in this way; it contributes to the energy efficiency of the construction.

- Temperature of the inner surface of the wall where this material is used is higher comparing with other walls. At the lower indoor temperatures, it makes people feel themselves more comfortable. The decrease of the indoor temperatures from $22^{\circ} \mathrm{C}$ to 20 or $10^{\circ} \mathrm{C}$ can cause considerable energy saving in heating (Fig. 3).

- Since Alker quickly solidifies, it does not need for any operations like lying under shadow, turning, and drying in contrast to the pure normal adobe and other additive adobes.

- As its heat retention has been increased more improved $(0.40 \mathrm{~W} / \mathrm{mK})$, it provides saving in fuel expenses that increase every year [35].

There has been no data about energy content of Alker. However, amount of the energy needed to manufacture Alker becomes lower because of the following reasons;

1 There is no need for fabrication in its manufacturing process,

2 It can be easily manufactured with less labor and

3 Its raw material can be easily obtained from nature by applying simple methods.

In a study carried out by Lawson, the energy content of the stabilized soil has been determined as $0,7 \mathrm{MJ} / \mathrm{Kg}$ [36]. The use of adobe, despite increasing the embodied energy related to the maintenance of the building, reduces the embodied energy in the life cycle of the building between 1.5 and 2 times compared with conventional materials [18]. In a study which the energy content of adobe houses have been analyzed by Shukla et al., it has been found that approximately $370 \mathrm{GJ}$ energy can be saved per year. The energy payback time for the adobe house is 1.54 years. By using low energy intensive materials, the mitigation of $\mathrm{CO}_{2}$ in the environment is reduced by an amount 101 tons/year. The adobe house is more environmentally friendly house in comparison to conventional buildings [37].

Pumice: Pumice is a natural material of volcanic origin produced by the release of gases during the solidification of lava and it has been used as aggregate in the production of Light Weight Concrete in many countries in the world. So far, the use of pumice has been dependent on the availability and has been limited to the countries where it is locally available or easily imported [39]. It is a volcanic and silicate-based material that has spongy appearance, glassy texture. Besides being silicate-based, its bulk density is usually lower than $1000 \mathrm{~kg} / \mathrm{m}^{3}$. Chemically, 


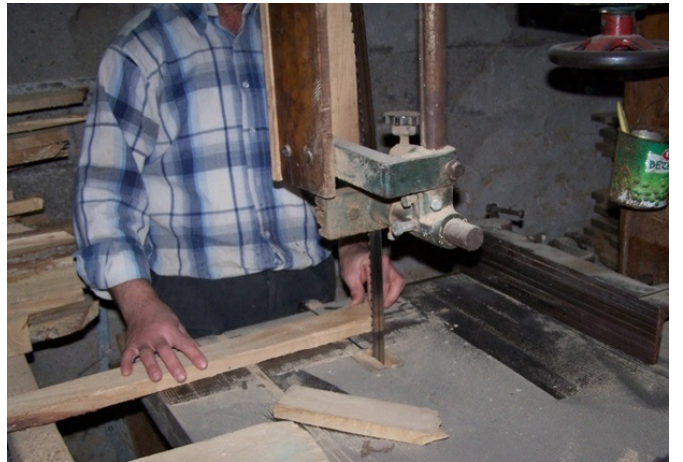

(a) Processing wood with electrical machines

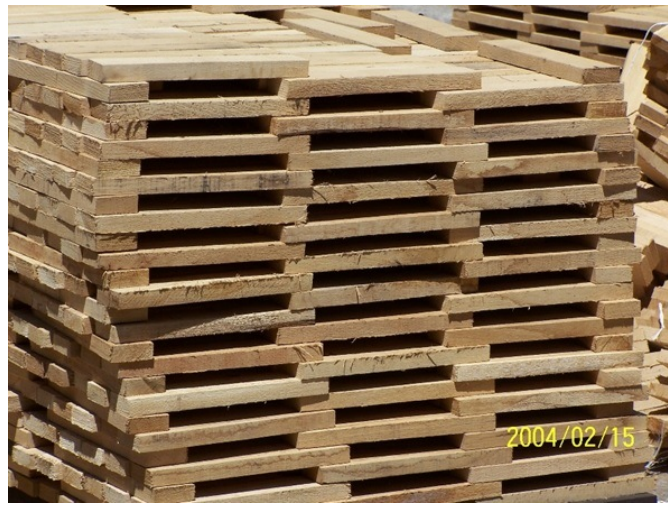

(c) Drying the cut wood in the open air

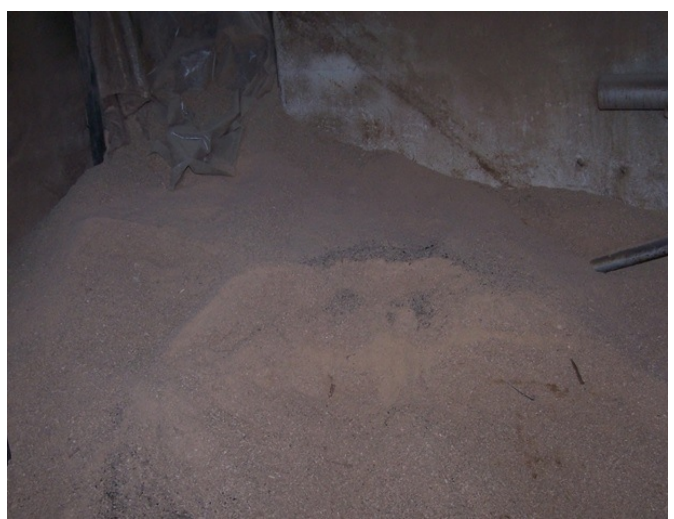

(b) Shavings that come after the cut of wood and is used in furnaces as fuel

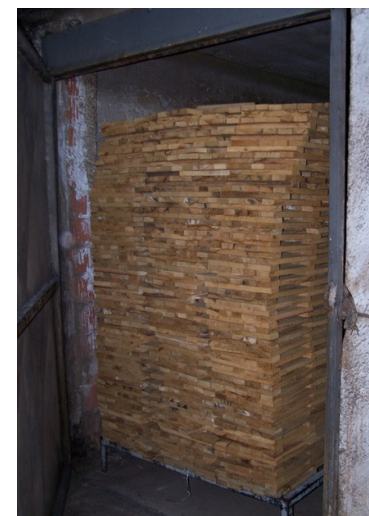

(d) Drying the wood in furnace to decrease the humid level of the wood dried in the open air

Fig. 1. Practices of preparing massive wood parquets
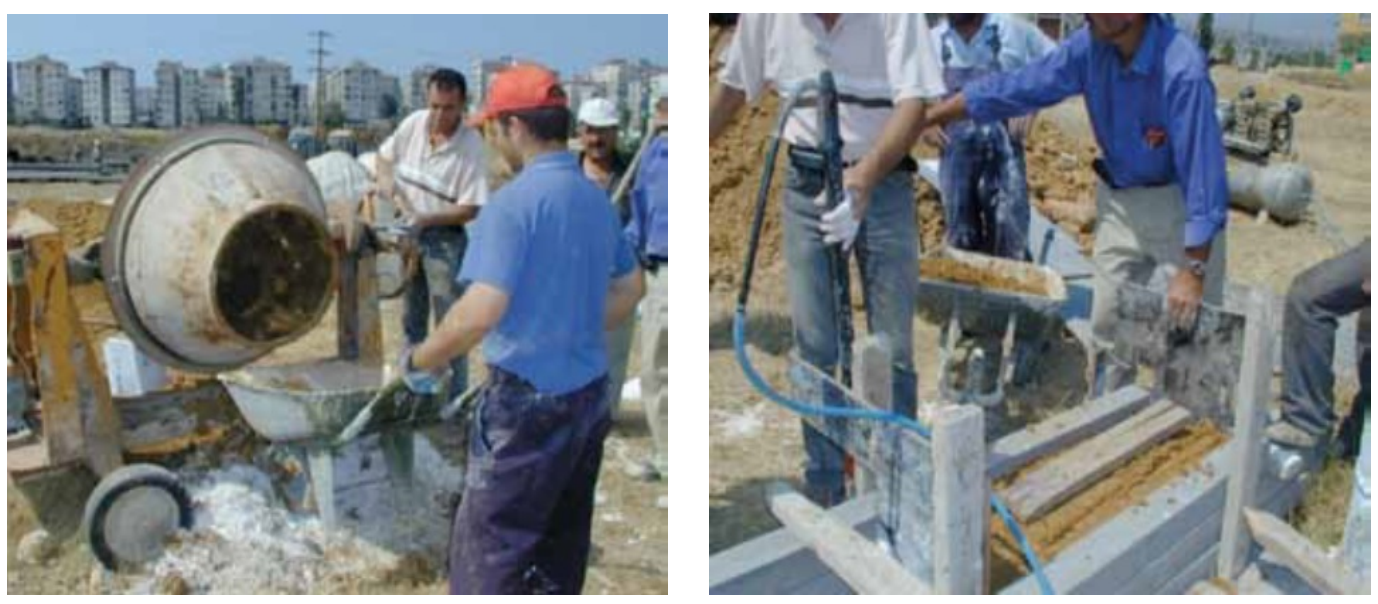

Fig. 2. Preparation of adobe block with gypsum [38]. 


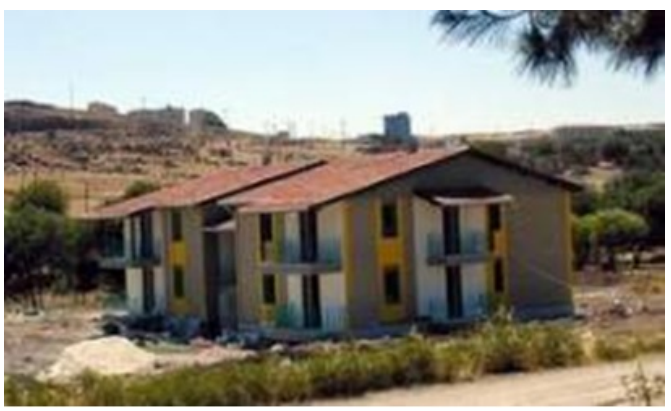

Fig. 3. Alker Building, four apartments on 2 stories at Urfa, Turkey

it may have a content of silica at about $75 \%$ rate. Pumice can be used in all fields where perlite is used [40]. Like perlite, does not require energy to expand, which affects its energy efficiency positively.

Pumice is used in the manufacture of wall blocks and, hollow block, and insulating plate as well as in the manufacture of plastering sand and screed sand. The bulk density of the $19 \times 33 \times 24 \mathrm{~cm}$ pumice block is $698 \mathrm{~kg} / \mathrm{m}^{3}$, and its heat conductivity parameter is $0,186 \mathrm{~W} / \mathrm{mK}$ [41]. In the manufacture of the $1 \mathrm{~m}^{3}$ pumice block with a dimension of $19 \times 39 \times 28,5 \mathrm{~cm}, 39,6$ 43,2 Mega Joule are used [42].

Its production contains simple procedures such as preparation of mortar, pressing and molding and does not require any industrial procedure except for the production of cement used in the mixture (Fig. 4 and 5 ).

Perlite: Perlite is a kind of volcanic glass that has relatively high water content, and it is typically formed by the cooling of the acidic lava of magma and then its breaking can be seen with the naked eye or microscope. When perlite with certain grain thickness and special forms, is heated between $900-1100{ }^{\circ} \mathrm{C}$, its bulk volume expands $4-20$ times and by bursting like corn, its density becomes very light [44].

The density of the expanded perlite changes between 30 - 190 $\mathrm{kg} / \mathrm{m}^{3}$, and this value is fairly low comparing to other construction materials. Its heat conductivity value is low and varies between $0.058-0.068 \mathrm{~W} / \mathrm{mK}$. Due to these favorable properties of Perlite, the expanded perlite material is widely used in the construction sector. Perlite is used in loose filling as grain, in concrete and grout additives, in the manufacture of plastering, grout and concrete by mixing with other materials, and as a construction component in the shape of block or panel and plate, and in the tile production. In addition, it is also used in the manufacture of sewer pipes, in the water insulations of the roofs and terraces, in the building of swimming pool, in highway construction as an asphalt filling material, in the railways as skidding sand, and in the buildings where water is easily accumulated or collected because of its resistance to freezing (Fig. 66 [45].

Because perlite is heated at about $900-1100{ }^{\circ} \mathrm{C}$ in the expansion process, huge amount of energy is consumed, and this negatively affects the energy efficiency of material. However, because it is light, and has a good heat conductivity, energy conservation in the construction is provided, which affects energy

efficiency positively.

Cellular concrete: It is a building material which contains a mixture of sand, cement, lime, plaster, aluminum and water and is produced as a result of a series of industrial processes. Cellular concrete is manufactured as unreinforced wall blocks, hollow block and insulation plates, and manufactured as reinforced wall, roof and floor stuffs, division panels.

In the production of $1 \mathrm{~m}^{3}$ cellular concrete, $1578 \mathrm{Mega}$ Joule of conventional energy and 140.3 Mega Joule of renewable energy are used. This rate seems fairly high comparing with alternative building materials. However, its heat conductivity value is between $0.085-0.16 \mathrm{~W} / \mathrm{mK}$, with this property, a considerable energy conversation which increases the energy efficiency of cellular concrete, is realized. In addition, cellular concrete panel used in the production of insulating panel has a thermal conductivity with $0.05 \mathrm{~W} / \mathrm{mK}$ [48]. This increases the energy efficiency of cellular concrete. Similarly, it has a unit weight of $300-600 \mathrm{~kg} / \mathrm{m}^{3}$ in the composition, making the structure lighter than the equivalent structure. This will decrease the dead load and load-bearing structural elements will contribute to a smaller cross-section. In addition, using the light weight structures in constructions increases the earthquake resistance as well.

Cellulosic Building Material with Boron Additive: It is important to underline that the impact of conventional insulation with a high level of industrial processing - such as expanded polystyrene (EPS) - is clearly higher than the impact of natural materials such as cork, wood fiber and sheep's wool, or recycled ones such as cellulose fiber. Thus, insulation such as EPS or polyurethane emits on average $7 \mathrm{~kg} \mathrm{CO}-\mathrm{Eq} / \mathrm{kg}$ with high consumptions of gas and petroleum. Therefore, it is fundamental to promote a radical change in the architectonic-structural design of buildings that facilitates their disassembly [18]. Among the isolation materials, low energy content materials such as cellulosic isolation materials that have recycle content have been preferred.

Cellulosic building material is the insulation material which is manufactured by treating waste papers with boron by using special processes. By weight, it includes $70-75 \%$ waste paper, and $23 \%$ boron components which are used to raise the feature of fire lessening. Added to the waste paper, the cellulose is used as raw material, too. Ammonium Phosphate or Sulfate and glass water, glue or wheat starch that provide the quality of sticking to the material, are added as additives. Cellulose wool whose heat conductivity parameter and density are $0,036-0,040 \mathrm{~W} / \mathrm{mK}, 30-90$ $\mathrm{kg} / \mathrm{m}^{3}$, respectively, is used as the shape of mattress and plate in the insulation of wall and roof for heat, sound and fire insulations (Fig. 77). The energy amount used in its manufacture is 1.75 $\mathrm{MJ} / \mathrm{Kg}$. Comparing with the other heat insulation materials, this value is fairly low (Table 2) [49].

The use of recycled content materials in its production, its low heat conductivity and less energy need for its manufacture add energy efficient quality to cellulosic insulation material with boron. 


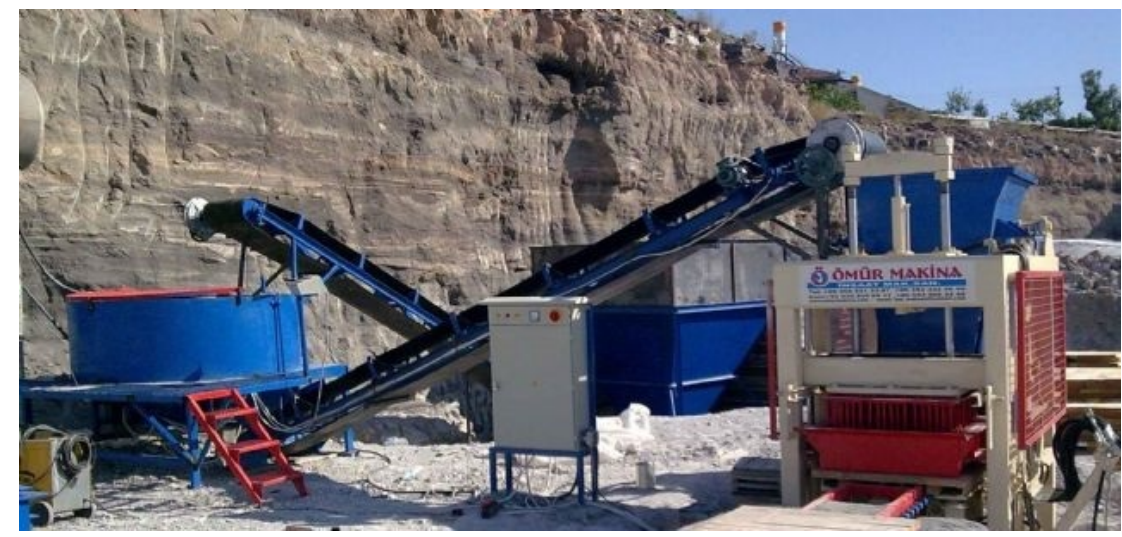

Fig. 4. Manufacture of pumice block with pumice block production machine in pumice resource [43].
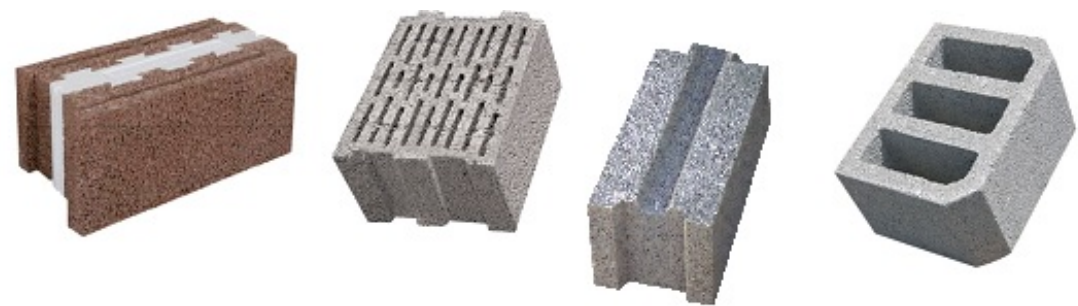

Fig. 5. Building components with pumice contained [41].
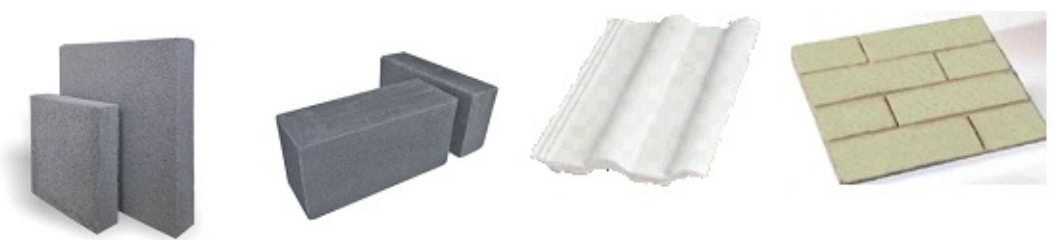

Fig. 6. Building components with perlite contained.
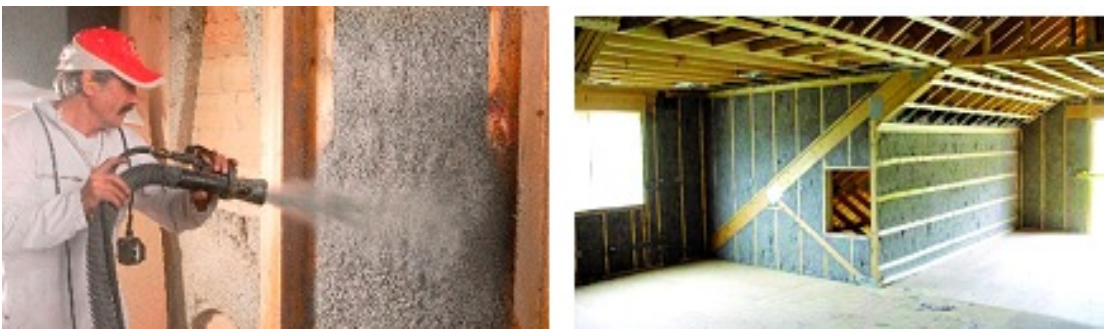

Fig. 7. Application of boron added cellulosic insulation material [50].

Tab. 1. The energy amounts spent in the manufacture of some insulation materials [49].

\begin{tabular}{cccc}
\hline Insulation Type & $\begin{array}{c}\text { The Energy Spent } \\
(\mathrm{Btu} / \mathrm{IB}), \mathbf{( M j} / \mathbf{k g})\end{array}$ & $\begin{array}{c}\text { The Weight of Material } \\
\text { Per Insulation Unit, Ibs. } \\
(\mathbf{k g})\end{array}$ & $\begin{array}{c}\text { The Energy Spent for } \\
\text { Each Insulation Unit } \\
\text { (Btu, Mj) }\end{array}$ \\
\hline Glass Wool & $12.000(27.9)$ & $0.379(0.17)$ & $4.550(4.8)$ \\
Mineral Wool & $6.500(15.1)$ & $0.458(0.21)$ & $2.980(3.1)$ \\
Stone Wool & $7.800(16.9)$ & $0.483(0.23)$ & $3.815(3.9)$ \\
Cellulose & $750(1.75)$ & $0.812(0.37)$ & $600(0.6)$ \\
Expanded Polystyrene & $48.000(111.6)$ & $0.375(0.17)$ & $18000(19.0)$ \\
Foam (EPS) & $30.000(69.08)$ & $0.476(0.22)$ & $14300(15.1)$ \\
Polyurethane & & & \\
\hline
\end{tabular}


Tab. 2. Embodied energy and $\mathrm{CO}_{2}$ Values for Aerojel blanket and other insulations [53].

\begin{tabular}{cccccc}
\hline Material & $\begin{array}{c}\text { Thermal } \\
\text { Conductivity } \\
(\mathbf{m W} / \mathbf{m}-\mathbf{K})^{\mathbf{1}}\end{array}$ & $\begin{array}{c}\text { Thermal } \\
\text { Resistance } \\
(\mathbf{R} \text {-value per } \\
\text { inch) }\end{array}$ & $\begin{array}{c}\text { Embodied } \\
\text { Energy (EE) } \\
(\mathbf{M J} / \mathbf{K g})\end{array}$ & $\begin{array}{c}\text { Embodied } \\
\mathbf{C O}_{2}\left(\mathrm{ECO}_{2}\right) \\
\left(\mathbf{k g} \text { of } \mathbf{C O}_{2} / \mathbf{k g}\right)\end{array}$ & $\begin{array}{c}\text { EE per } \\
\text { Thermal } \\
\text { Resistance } \\
\text { (EEJR-value } \\
\text { per inch) }\end{array}$ \\
\hline $\begin{array}{c}\text { Aero gel } \\
\text { blanket }\end{array}$ & 14 & 10.3 & $53.0^{1}$ & $4.2^{1}$ & 5.15 \\
$\begin{array}{c}\text { Fiberglass } \\
\text { (Recycled } \\
\text { Glass) }\end{array}$ & 40 & 3.8 & $28.0^{2}$ & $1.4^{2}$ & 7.37 \\
$\begin{array}{c}\text { Fiberglass } \\
\text { (Virgin Glass) } \\
\text { Expanded }\end{array}$ & 40 & 3.8 & $39.2^{2}$ & $1.9^{2}$ & 10.32 \\
$\begin{array}{c}\text { Polystyrene } \\
\text { Polyisocyanurate }\end{array}$ & 24 & 4.5 & $111.6^{3}$ & $3.0^{2}$ & 24.80 \\
\hline
\end{tabular}
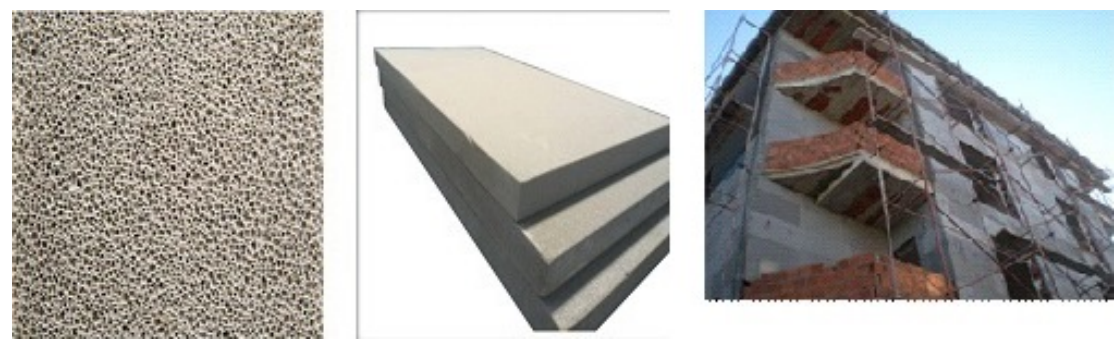

Fig. 8. Building components with wasted ceramic contained and its application.

Aero gels: Aero gels which are today's advanced technological products are used in construction sector as heat and fire insulation material. Components in Aerogel are silicon based solid agents in which the liquid component of the gel is replaced with air. The surface of aero gels consisting of millions of small holes is similar to a sponge: $99,8 \%$ of it is occupied by air and it is a very good insulation. Since they have a translucent nature, they are called "freeze smoke" or "solid smoke". When compared with glass which is another silica based agent, aero gels have 1000 times less density and a porous structure. The holes whose magnitude is about one/billionth of millimeter occupy the inside of material like a net. The surrounding of the holes is covered by a different material [51].

Aero gels have the lowest thermal conductivity comparing with all additive agents. The heat conductivity of an aero gel blanket which is produced to be used as insulation material changes between $0.011-0.013 \mathrm{~W} / \mathrm{m}-\mathrm{K}$ and $0.004 \mathrm{~W} / \mathrm{m}-\mathrm{K}$ at $38^{\circ} \mathrm{C}\left(100^{\circ} \mathrm{F}\right)$ [52].

The production process of aero gels requires high dense industrial processes in which huge amount of energy is consumed, such as spilling, gelling, super critical distancing, and drying. However, energy need for producing aerogels is less comparing with EPS (Expanded Polystyrene) and Pol. (Polyisocyanurate). Otherwise, its heat conductivity and density values remain at very low levels comparing with other insulation materials [53]. Properties of some other insulation materials about energy efficiency are given below;

Closed porous ceramic foam insulation material: It is environmentally friendly material that is completely produced by treating ceramic waste materials at $1200^{\circ} \mathrm{C}$. This material is still being advertised. This material consists of $100 \%$ inorganic material and has the following specification; closed porous, nonflammable, low density, non-expansion ratio over time, water proof, not allowing insect sheltering, antitoxic. Its thermal conductivity and density values are $0.63 \mathrm{~W} / \mathrm{mK}$, and $300-400 \mathrm{~kg} / \mathrm{m}^{3}$, respectively. Furthermore, its dimension is $500 \times 1000 \mathrm{~mm}$ while its thickness varies between $50-60 \mathrm{~mm}$. It's waterproof although this material is used as heat insulation inside the wall and the floor (Fig. 87. Sound transmission loss measurements at $28 \mathrm{~dB}$ [54]. Energy consumption in the production stage is relatively high due to high temperature at 1200 ${ }^{\circ} \mathrm{C}$. In addition, recycled content materials are used in its production and it has low heat conductivity. These features add energy efficient quality to the closed porous ceramic foam materials. Energy related features of building materials have been analyzed under the four headings (local materials, recycled content, renewable sources, low density industrial process) in the Table 3-4.

\section{Conclusions}

In the evaluation of the energy efficiencies of the building materials which are selected in this study in terms of the criteria described before, it is seen that natural materials have more positive properties (Table 5). Natural wood material has been found positive in terms of all criteria. Moreover, because it is a local material, the energy consumed for its transportation to the con- 
Tab. 3. The evaluation of some building materials in terms of energy efficiency

\section{Energy efficiency criteria}

氙

Locally produced material, but if the

Wood imported wood is used, it loses this property.

Adobe soil and

Gypsums mud brick

Cellular concrete

Cellulosic insulation material

Aerogels ceramic thermal insulation material

gypsum are locally available raw materials.

Pumice aggregates are locally available raw materials.

Perlite aggregates are locally available row materials.

The raw materials which are used in cellular concrete manufacture can be locally provided.

It is produced with local raw materials such as boron and waste paper.

Its raw material is provided from abroad.

Its raw material is obtained from the waste of ceramic material which is locally produced.

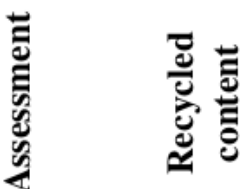

The waste occurring in its procession can be recycled.

Pumice aggregates can be reused.

Perlite aggregates used reused.

The waste

matters occurring during the
manufacturing
process are
reevaluated.

The basic raw material of the product is wastepaper
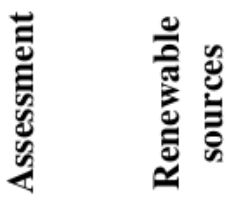

竞

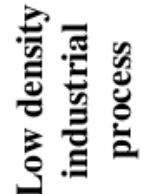

Its staple is a vegetal and renewable source

Soil can be described as unlimited resource. Pumice

aggregate is a limited resource. Perlite aggregate is a limited resource.

Natural wood production doesn't include industrial process.

Only in the production of gypsum, there is industrial process. Pumice aggregate production doesn't include industrial process.

High energy is consumed in the production process.

It is produced with limited natural sources.

High energy is consumed in the production process.

Paper is produced from a renewable source, wood.

Low level of energy is consumed in the + production process.

There is no Produced in recycled material - limited natural resources.

High energy is consumed during the production process.

Soil can be + Produced from + described as

High energy is unlimited resource. consumed during the production process. 
Tab. 4. The evaluation of some building materials in terms of energy efficiency

\begin{tabular}{|c|c|c|c|c|c|c|c|c|c|}
\hline & & & & Ene & gy ef & ciency criteria & & & \\
\hline & & 彎高 & 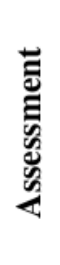 & 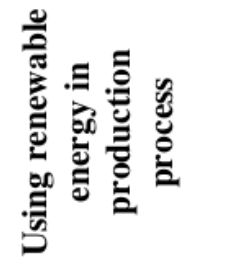 & 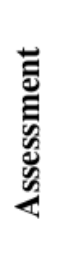 & 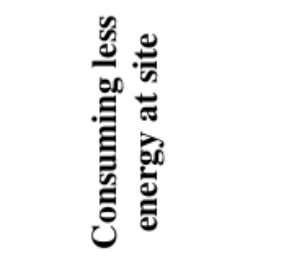 & 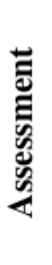 & 焉 & 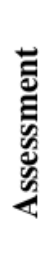 \\
\hline & Wood & $\begin{array}{l}\text { Processed } \\
\text { with } \\
\text { manpower. }\end{array}$ & + & $\begin{array}{l}\text { Used drying } \\
\text { process the } \\
\text { wood. }\end{array}$ & + & $\begin{array}{l}\text { Production is done } \\
\text { on site with } \\
\text { manpower. }\end{array}$ & + & $\begin{array}{c}0,13-0,20 \\
\mathrm{~W} / \mathrm{mK}\end{array}$ & + \\
\hline & $\begin{array}{l}\text { Gypsums } \\
\text { mud brick }\end{array}$ & $\begin{array}{l}\text { Used mixing } \\
\text { and molding } \\
\text { adobe. }\end{array}$ & + & $\begin{array}{l}\text { Solar energy is } \\
\text { used when } \\
\text { drying the } \\
\text { adobe. }\end{array}$ & + & $\begin{array}{l}\text { Production is done } \\
\text { on site with } \\
\text { manpower. }\end{array}$ & + & $0.40 \mathrm{w} / \mathrm{mK}$ & + \\
\hline & Pumice & $\begin{array}{l}\text { Used in the } \\
\text { production of } \\
\text { pumice } \\
\text { building } \\
\text { component }\end{array}$ & + & $\begin{array}{l}\text { Used drying } \\
\text { pumice } \\
\text { building } \\
\text { product. }\end{array}$ & + & $\begin{array}{l}\text { Additional energy } \\
\text { isn't used in } \\
\text { practice. }\end{array}$ & + & $0,186 \mathrm{~W} / \mathrm{mK}$ & + \\
\hline & Perlite & $\begin{array}{l}\text { Not used in } \\
\text { the production } \\
\text { process. }\end{array}$ & - & $\begin{array}{l}\text { Not used } \\
\text { renewable } \\
\text { energy. }\end{array}$ & - & $\begin{array}{l}\text { Additional energy } \\
\text { isn't used in } \\
\text { practice. }\end{array}$ & + & $\begin{array}{c}0,058-0,068 \\
\mathrm{~W} / \mathrm{mK}\end{array}$ & + \\
\hline 离 & $\begin{array}{l}\text { Cellular } \\
\text { concrete }\end{array}$ & $\begin{array}{l}\text { Not used in } \\
\text { the production } \\
\text { process. }\end{array}$ & - & $\begin{array}{c}\text { Used in } \\
\text { production } \\
\text { process } \\
\text { approximately } \\
\% 8 .\end{array}$ & + & $\begin{array}{l}\text { Additional energy } \\
\text { isn't used in } \\
\text { practice. }\end{array}$ & + & $\begin{array}{c}0,085-0,16 \\
\mathrm{~W} / \mathrm{mK}\end{array}$ & + \\
\hline & $\begin{array}{c}\text { Cellulosic } \\
\text { insulation } \\
\text { material }\end{array}$ & $\begin{array}{l}\text { Used when } \\
\text { recovery and } \\
\text { separation of } \\
\text { waste paper. }\end{array}$ & + & $\begin{array}{l}\text { Not used } \\
\text { renewable } \\
\text { energy. }\end{array}$ & - & $\begin{array}{l}\text { Only in cellulosic } \\
\text { wool } \\
\text { implementation, } \\
\text { energy is used in } \\
\text { pumping. }\end{array}$ & + & $\begin{array}{c}0.036-0,040 \\
\mathrm{~W} / \mathrm{mK}\end{array}$ & + \\
\hline & Aerogels & $\begin{array}{l}\text { Not used in } \\
\text { the production } \\
\text { process. }\end{array}$ & - & $\begin{array}{l}\text { Not used } \\
\text { renewable } \\
\text { energy. }\end{array}$ & - & $\begin{array}{l}\text { Additional energy is } \\
\text { used in practice. }\end{array}$ & + & $\begin{array}{c}0.011-0.013 \\
\mathrm{~W} / \mathrm{mK}\end{array}$ & + \\
\hline & $\begin{array}{c}\text { Waste } \\
\text { ceramic } \\
\text { thermal } \\
\text { insulation } \\
\text { material }\end{array}$ & $\begin{array}{l}\text { Not used in } \\
\text { the production } \\
\text { process. }\end{array}$ & - & $\begin{array}{l}\text { Not used } \\
\text { renewable } \\
\text { energy. }\end{array}$ & - & $\begin{array}{l}\text { Additional energy } \\
\text { isn't used in } \\
\text { practice. }\end{array}$ & + & $0.036 \mathrm{~W} / \mathrm{mK}$ & + \\
\hline
\end{tabular}


Tab. 5. Assessments of building materials in terms of energy efficiency

\begin{tabular}{|c|c|c|c|c|c|c|c|c|c|}
\hline \multicolumn{10}{|c|}{ Assessment of Energy Efficient Criteria } \\
\hline & & 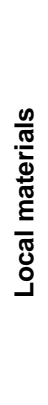 & 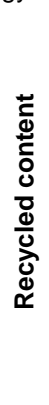 & 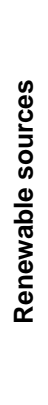 & 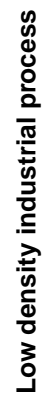 & 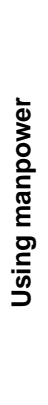 & 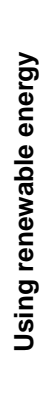 & 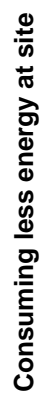 & 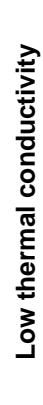 \\
\hline \multirow{8}{*}{ 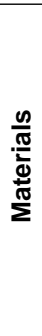 } & Wood & + & + & + & + & + & + & + & + \\
\hline & Gypsums mud brick & + & + & + & + & + & + & + & + \\
\hline & Pumice & + & + & - & + & + & + & + & + \\
\hline & Perlite & + & + & - & - & - & - & + & + \\
\hline & Cellular concrete & + & + & - & - & - & + & + & + \\
\hline & Cellulosic insulation material & + & + & + & + & + & - & + & + \\
\hline & Aerogels & - & - & - & - & - & - & + & + \\
\hline & Waste ceramic insulation material & + & + & + & - & - & - & + & + \\
\hline
\end{tabular}

struction site will decrease, affecting its energy efficiency positively. Furthermore, since it is produced with high man power instead of the industrial procedures, it uses various renewable energy sources in the production process and uses more man power in the construction process. All of them are the properties that reduce the energy consumption considerably. Due to its high thermal performance, it improves the energy efficiency of the construction providing heat conservation.

Besides, only solar energy is used in the production of adobe with gypsum whose raw material is just soil. There is no energy consumption for its transportation since it can be produced in places near the construction site. In addition, due to its high thermal performance, it affects the energy efficiency of the construction positively.

Considering bims, perlite and cellular concrete which are used for similar purposes, bims seems more energy efficient. Its production does not have intense industrial processes and it needs more man power in its production. Furthermore, solar energy is used in its production. All of them are the properties that raise its energy efficiency.

As manufacturing aero gels used as insulation material which includes intense industrial processes, more energy will be consumed and so its energy efficiency will be affected negatively. Due to the fact that its raw material is not extracted from domestic (local) resources, energy expense for transportation will rise. However, being very low heat conductivity coefficient is an effective property in terms of energy conservation.

Additionally, cellulosic insulation material can be manufactured from local and waste materials, its raw material are renewable, it is manufactured with low energy, and it has a fairly low heat conductivity value. All of them are the important properties affecting energy efficiency positively.

According to the evaluation carried out in the study, the heat conductivity values of the examined materials are at low levels. In the perception of the materials as energy efficient, role of the heat conductivity parameter is significant. Since the constructions spend the large part of their energy consumption during their life cycles at the usage stage. In this process, in order to reduce the energy consumption of constructions, it is needed to provide heat conservation, and for this, it is important to select the materials with low heat conductivity.

Furthermore, it is highlighted that the use of renewable energy in the production of the construction materials is not very widespread, and that amount of energy consumed in the manufacture of some materials is high. As a result, instead of using such materials, alternative materials satisfying the same conditions should be preferred.

In the definition of construction materials as environmentally friendly and ecological building materials, energy efficiency is an important parameter. The long term energy costs in the running of a construction largely depend upon the materials used in the building of the construction. A material which is the most appropriate in terms of the construction technique, but more expensive comparing with others can lead to low energy cost considering all the energy consumption during the life-cycle. For this reason, when a selection for the material is made considering the energy efficiency, it is needed to take the energy consumptions at all the stages including the obtainment of the materials from their source, its convert to the building material, its transportation, its usage, its destruction and obliteration/recycling as a whole. Using energy efficient materials decreases the consumption of fossil based energy resources, and also considerably makes contribution to overcome the environmental problems such as global warming and climate changing. 


\section{References}

1 Hassouneh K, Al-Shboul A, Salaymeh A, Influence of windows on the energy balance of apartment buildings in Amman, Energy Conversion and Management, 51(8), (2010), 1583-1591, DOI 10.1016/j.enconman.2009.08.037

2 Anonymous, Turkey: Environmental Issues, Energy Information Administration, 2003, http://www.eia.doe.gov/emeu/cabs/turkenv.html

3 Anonymous, Statistical Review of World Energy, British Petroluem, 2013, http://www.bp.com/content/dam/bp/ pdf/Energy-economics/statistical-review-2013/ BP-statistical-review-of-world-energy-2013-full-report. pdf

4 Türkyılmaz 0, What happens to Turkey in energy?, Engineer and Machinery, 617, (2011), 40-46, http://www.mmo.org.tr/yayinlar/dergi_ goster. php?kodu=1139\&dergi $=1$

5 Enerji ithalatı 60 milyar dolar, http://www.aa.com.tr/tr/ekonomi/ 139734--enerji-ithalati-60-milyar-dolar

6 Anonymous, Lighting the Way: Toward a Sustainable Energy Future, Inter Academy Council, 2007, http://www.interacademycouncil.net/ File. aspx?id=24548

7 Keskin T, Lighting the Way: Toward a Sustainable Energy Future, Republic of Turkey, Ministry of Environment and Urbanism, 2010, http://iklim.cob.gov.tr/iklim/Files/Binalar\%20Sektoru\% 20Mevcut\%20Durum\%20Degerlendirmesi\%20Raporu.pdf

8 Esin T, Appropriate Material Selection for Sustainable Building, Building Magazine, 291, (2006), 83-86.

9 Mohsen MS, Akash BA, Some prospects of energy savings in buildings Amman, Energy Conversion and Management, 42(11), (2001), 1307-1315, DOI 10.1016/S0196-8904(00)00140-0

10 Lam JC, Wan KKW, Tsang CL, Yang L, Building energy efficiency in different climates, Energy Conversion and Management, 49(8), (2008), 23542366, DOI 10.1016/j.enconman.2008.01.013

11 Anonymous, Energy Productivity Law, Republic of Turkey, The Ministry of Energy and Natural Resources, 2007, http://www.resmigazete.gov. tr/eskiler/2007/05/20070502-2.htm

12 Anonymous, Regulations of Energy Performance in Building, Republic of Turkey, The Ministry of Public Works and Settlement, 2008, http://www. resmigazete.gov.tr/eskiler/2008/12/20081205-9.htm

13 Anonymous, Thermal Insulation Requirements for Buildings, Turklsh Standard 825, Republic of Turkey, Turkish Republic, The Ministry of Public Works and Settlement, 2008, www.mmo.org.tr/resimler/.../ cf3e258fbdf3eb7_ek.pdf

14 Utkutuğ G, Interaction between the Building Generated Systems and Importance of Teamwork Plumbing Engineer Architect Cooperation, In: Chamber of Machine Engineering (ed.), IV. National Mechanical Engineering Congress and Exhibition, Conference Proceedings, 1999, pp. 21-36.

15 Çakmanus i, Böke A, Passive Solar heating and cooling of buildings, Building Magazine, 235, (2001), 83-88.

16 Kumar A, Buddhi D, Chauhan DS, Indexing of Building Materials with Embodied, Operational Energy and Environmental Sustainability with Reference to Green Buildings, Journal of Pure and Applied Science \& Technology, 2(1), (2012), 11-22.

17 Jayasinghe C, Embodied energy of alternative building materials and their impact on life cycle cost parameters, In: The International Structural Engineering and Construction Society (ed.), Conference Proceedings, 2001, pp. 1-20.

18 Bribian I, Capilla A, Uson A, Life cycle assessment of building materials: Comparative analysis of energy and environmental impacts and evaluation of the eco-efficiency improvement potential, Building and Environment, 46(5), (2011), 1133-1140, DOI 10.1016/j.buildenv.2010.12.002

19 Lee B, Trcka M, Hensen JLM, Embodied energy of building materials and green building rating systems - a case study for industrial halls, Sustainable Cities and Society, 1(2), (2011), 67-71, DOI 10.1016/j.scs.2011.02.002

20 Reddy BVV, Sustainable materials for low carbon buildings, International Journal of Low-Carbon Technologies, 4(3), (2009), 175-181, DOI $]$ 10.1093/ijlct/ctp025

21 Huberman N, Pearlmutter AD, Life-cycle energy analysis of building materials in the Negev desert, Energy and Buildings, 40(5), (2008), 837-848, DOI 10.1016/j.enbuild.2007.06.002

22 Reddy BVV, Jagadish KS, Embodied energy of common and alternative building materials and technologies, Energy and Buildings, 35(2), (2008), 129-137, DOI DOI 10.1016/S0378-7788(01)00141-4

23 Atkinson C, Hobbs S, West J, Edwards S, Life cycle embodied energy and carbon dioxide emissions in buildings, Industry and Environment, 19(2), (1996), 29-31. file://M:|online|publi|ieqr|ieqr192.html.

24 Berge B, The Ecology of Building Materials, Architectural Press; Oxford, 2009.

25 Canadian Architect, Measures of Sustainability, Architectural Science Forum, 2002, http://www.canadianarchitect.com/asf/ perspectives_sustainibility/pdf

26 Alcorn A, Embodied Energy and CO2 Coefficients for NZ Building Materials, Centre for Building Performance Research; Wellington, 2003.

27 Buchanan A, Levine B, Wood-based building materials and atmospheric carbon emissions, Environmental Science and Policy, 2(6), (1999), 427-437, DOI 10.1016/S1462-9011(99)00038-6

28 Goverse T., Wood innovation in the residential construction sector; opportunities and constraints resources, Conservation and Recycling, 34(1), (2001), 53-74, DOI 10.1016/S0921-3449(01)00093-3

29 Gustavsson L, Pingoud K, Sathre R, Carbon dioxide balance of wood substitution: comparing concrete- and wood-framed buildings, Mitigation and Adaptation Strategies for Global Change, 11(3), (2006), 667-691, DOI 10.1007/s11027-006-7207-1

30 Jagadish KS, The progress of stabilised soil construction in India, National Seminar on Application of stabilised mud blocks in Housing and Building, In: Korsunsky AM (ed.), Proceedings of National seminar on Application of Stabilised Mud Blocks in Housing and Building, Conference Proceedings; Bangalore, India, 1988, pp. 17-43.

31 Reddy BVV, Studies on static soil compaction and compacted soil-cement blocks for walls, PhD thesis, Indian Institute of Science; Bangalore, India, 1991.

32 Lunt MG, Stabilised soil blocks for building, In: Pless VS, Huffman WC (eds.), Building in hot climates. A selection of overseas building notes, ICCROM; London, 1980, pp. 127-144.

33 Walker $\mathbf{P}$, Strength, durability and shrinkage characteristics of cement stabilised soil blocks, Cement and Concrete Composites, 17(4), (1995), 301310, DOI 10.1016/0958-9465(95)00019-9

34 Walker P, Reddy BVV, Mesbah A, Morel J, The case for compressed Earth block construction, 6th International Seminar on Structural Masonry for Developing Countries, In: Korsunsky AM (ed.), Proceedings of 6th International Seminar on Structural Masonry for Developing Countries, Allied Publishers Ltd; Bangalore, India, 2000, pp. 27-35.

35 Kafesçioğlu R, Gürdal E, Modern Building Materials- Alker Gypsums Mud-Brick, Ministry of Energy of Natural Resources and Shell Publishing; İstanbul, 1985.

36 Lawson B, Building Materials, Energy and the Environment: Towards Ecologically Sustainable Development, Red Hill, Royal Australian Institute of Architects; Australia, 1996.

37 Shukla A, Tiwari GN, Sodha MS, Embodied energy analysis of adobe house, Renewable Energy, 34(3), (2009), 755-761, DOI ] 10.1016/j.renene.2008.04.002

38 Işık B, Adobe Buildings and Earthquake Reality, Elazı̆̆ Architect Magazine, 4, (2011), 7-18. 
39 Khandaker M, Hossain A, Properties of volcanic pumice based cement and lightweight concrete, Cement and Concrete Research, 34(2), (2004), 283-291, DOI 10.1016/j.cemconres.2003.08.004

40 Sancak E, Şimşek O, Subaşı S, Pumice Concrete in the Turkey Housing Production, 4th International Advanced Technologies Symposium, In: Proceedings of 4th International Advanced Technologies Symposium; Karabuk, Turkey, 2005, pp. 1063-1068

41 Pumice Block, http://www.blokbims.com.tr/gecmeli.html

42 Gündüz L, Sonugelen S, Relation of Bimsblock - Ecology and Environmentalist Buildings, BİMSADERGİ, 6, (2012), 5-9.

43 Making concrete block machine HKM 8000, http://www . firmasayfasi.com/urun/eoaea/ hkm-8000-manuel-beton-blok-uretim-makinasi/

44 Hodul Y, Industrial Profile of Expanded Perlite Production, Directorate General for Industrial Research and Development, The Ministry of Industry and Trade, Pepublic of Turkey, 2009, http://sagm.sanayi.gov.tr/ Files/Documents/genlestirilmis-perlit-ure-09112010152919. dioc

45 Akıncı H, Today's thermal insulation materials applied, their properties, application techniques and cost analysts, Master Thesis, Sakarya University; Sakarya, Turkey, 2007.

46 http://www . peryum. com.tr/index.php?pg=urunler\&dil=tr

47 http://www.persanyapi.com.tr/

48 Environmental Product Declaration, Turk Ytong A.S. According to ISO 14025., 2011.

49 Çelik AG, Technical Specification and Application Area of Boron Additive Cellulosic Insulation Material, Second National Boron Workshop, In: Instıtute of National Boron Investigation (ed.), Proceedings of Second National Boron Workshop; Ankara, Turkey, 2008, pp. 295-301.

50 http://www. ozturkbor.com

51 Aerojel,http://tr.wikipedia.org/wiki/Aerojel

52 Aerojels, http://www.aspenaerogels.com.tr/features/ morphology.html

53 Spaceloft insulation, Aspen-aerogels, 2011. Presentation Brochure.

54 Kaleserafoam, 2011. Presentation Brochure. 